\title{
Large zonal and temporal shifts in crops and cultivars coincide with warmer growing seasons in Finland
}

\author{
Pirjo Peltonen-Sainio ${ }^{1}$ (D) - Lauri Jauhiainen ${ }^{2}$
}

Received: 11 March 2020 / Accepted: 2 July 2020 / Published online: 18 July 2020

(C) The Author(s) 2020

\begin{abstract}
In Finland, crop choices are limited, and cultivation is only possible in the regions where production risks and uncertainties are manageable. Climate change progresses rapidly at high latitudes and the thermal growing season is projected to become substantially longer in the future. This study aimed to monitor the regional shifts in major, secondary, minor and novel crops during 1996-2016 in Finland. We used long-term data from the Finnish Food Agency and evaluated changes in time to reach maturity of cultivars of model crops by using official variety trial data. Substantial changes were recorded in cultivation areas of crops, including expansion into new regions. Some of the traditional major crops such as oats $(-20 \%$, i.e. $-75,700$ ha from 1996 to 2016$)$, barley $(-19 \%,-105,700 \mathrm{ha})$ and potatoes $(-28 \%,-4000 \mathrm{ha})$ have paved the way for emergent crops like faba beans (increase in area from 58 to 14,800 ha), peas (from 5700 to 13,400 ha), caraway (from 1900 to 18,400 ha) and spring oilseed rape (from 700 to 27,800 ha). Expansion per se was primarily enabled by climate warming, but success requires well-adapted cultivars, existing or emerging markets and industries or exports as well as motivating prices, policy support and valued ecosystem services.
\end{abstract}

Keywords Climate change $\cdot$ Cultivation area $\cdot$ Major crop $\cdot$ Minor crop $\cdot$ Northern Europe

\section{Introduction}

The agro-climate zones will migrate northwards and the suitable areas for crop growth will change in Europe due to climate warming (Ceglar et al. 2019). Gradual warming has already contributed to a lengthening of the growing season in favour of the northern Europe (Ceglar et al. 2019). Due to climate change, the growing season in Europe will be prolonged in by $1.5-2$ months by the end of this century in the RCP8.5 scenario (Ruosteenoja et al. 2016). In Finland, the

Communicated by Luis Lassaletta

Electronic supplementary material The online version of this article (https://doi.org/10.1007/s10113-020-01682-x) contains supplementary material, which is available to authorized users.

Pirjo Peltonen-Sainio

pirjo.peltonen-sainio@luke.fi

1 Natural Resources Institute Finland (Luke), Latokartanonkaari 9, FI-00790 Helsinki, Finland

2 Natural Resources Institute Finland (Luke), FI-31600 Jokioinen, Finland thermal spring season is projected to start earlier, autumn to end later, and thermal summers will lengthen by some 10 days per $1{ }^{\circ} \mathrm{C}$ increase in the temperature of the region, while winters will get shorter at an even higher rate of change (Ruosteenoja et al. 2019). The likelihood having of years without a thermal winter (the daily mean temperature < $0{ }^{\circ} \mathrm{C}$ ) will increase markedly by $2040-2069$ (Ruosteenoja et al. 2019). Ceglar et al. (2019) estimated that the northward migration of agro-climate zones may be two times faster in the next decades than over the past 40 years. Changes in crop and cultivar choices are anticipated as advances in the sowing time become likely (Kaukoranta and Hakala 2008), which together with the changing climate are apt to alter phenological development especially in Northern Europe (Olesen et al. 2012).

Climate change has already impacted global food production and Europe is among the continents experiencing the most negative impacts (Ray et al. 2019). Rising temperatures have reduced the yield gains for wheat (Triticum aestivum $\mathrm{L}$.) across continents with an estimated $6 \%$ decline in global wheat production per each $1{ }^{\circ} \mathrm{C}$ further increase in temperature (Asseng et al. 2015). Wheat production may also become more variable in the future climate (Asseng et al. 2015). The prolongation of the growing seasons and coinciding elevation 
in $\mathrm{CO}_{2}$ concentrations in Finland, however, are expected to increase cereal production, although reverse impacts are predicted in the case that the temperature increases more than + $4{ }^{\circ} \mathrm{C}$ (Rötter et al. 2011). Estimated yield gains may also be threatened by higher risks caused by pests and diseases (Hakala et al. 2011; Juroszek and von Tiedemann 2013). The future warming of Northern Europe may be favourable or unfavourable depending on the crop. For example, protein crops may benefit from warmer high-latitude conditions contrary to the situation in Southern European countries (Manners et al. 2020).

Climatic extremes such as severe drought, heatwaves and flooding result in yield penalties for major crops like wheat (Mäkinen et al. 2018) and these events will occur at an increasing pace in the future (Scoccimarro et al. 2015; Zampieri et al. 2019). Increases in weather variability may be a serious threat to the expansion of novel crops that might in general benefit from warming (Peltonen-Sainio et al. 2011). Cultivars adapted to some specific region may have features that improve their capacity to cope with extreme weather events (Mäkinen et al. 2018). With well-adapted future cultivars, environmental risks may also be better mitigated (Niero et al. 2015). Such features are important when targeting novel breeds that are tailored to cope with future conditions (George et al. 2017).

The aim of this study was to monitor whether anticipated changes in crop choices as well as the expansion of minor crops into new areas and earlier maturation of cultivars were experienced during 1996-2016 in Finland, which represents the high latitudes of Europe with a high pace of climatic change. All these changes were in general considered as likely manifestations of adaptation to already on-going changes in the growing conditions. Furthermore, we aimed to assess whether farmers who have recognised changes in growing conditions have already been active in expanding crop areas as an adaptation measure.

\section{Materials and methods}

\section{Assessing changes in the extent of crops and regional growing degree days}

Shifts in crops across Finland were examined at 5-year intervals: in 1996, 2001, 2006, 2011 and 2016. The crops that were included in this study were either current prime crops or minor/novel crops, including spring barley (Hordeum vulgare L.), oats (Avena sativa L.), wheat and rye (Secale cereale L.), winter wheat and rye, spring turnip rape (Brassica rapa L.) and oilseed rape (Brassica napus L.), winter rapeseed (either turnip rape or oilseed rape, henceforth together referred to as rapeseed), peas (Pisum sativum L.) and faba beans (Vicia faba L.), potatoes (Solanum tuberosum L.), sugar beet (Beta vulgaris var. altissima L.), caraway (Carum carvi L.), buckwheat (Fagopyrum esculentum L.), flax (Linum usitatissimum L.), hemp (Cannabis sativa L.) and maize (Zea mays L.). Data for perennial grasslands (mainly used as silage) and environmental fallows were also gathered as references for land use.

To analyse spatiotemporal shifts in crop areas, the official data from the Finnish Food Authority was used. The data was based on obligatory farmer reporting that was randomly verified by the authorities. It covered more than one million field parcels in a year and hence, we used a single year data at 5year intervals. The data included the coordinates of each field parcel, the cultivated crop and the cultivar. The number of parcels for each crop was categorised into six groups: 1-9, $10-19,20-39,40-79,80-160$ and $>160$ in a $10 \times 10 \mathrm{~km}$ grid. The total number of parcels in a grid varied depending on agricultural land available in a region and was highest in the south and west coastal regions of Finland and lowest in the inland, eastern and northern parts of the country (PeltonenSainio et al. 2017).

To link the changes in the cultivation frequencies of the crops to climate warming, two 30-year time periods of 1970-1990 (earlier) and 1985-2015 (later) were used. They were partly overlapping to have 30 years data for both periods. We estimated the relative frequencies (i.e. number of times the outcome occurs or could have occurred) of growing seasons with different growing degree days from the time of sowing to mid-September (900, 1000, 1100, 1200, 1300 and $1400{ }^{\circ} \mathrm{Cd}$ with $5^{\circ} \mathrm{C}$ as the base temperature) in 13 crop production regions in Finland. Mid-September was used as the final date for harvests as thereafter the likelihood for total crop failure is high (Peltonen-Sainio et al. 2016). Weather data was from the Finnish Meteorological Institute. The temperature sum was calculated from the potential sowing day, which was estimated according to the actual sowing days in the Finnish official variety trials coordinated by Luke. On average, the difference in the temperature sum between the beginning of the thermal growing season and the potential sowing day was $30^{\circ} \mathrm{Cd}$. The relative frequencies for different growing degree days were categorised as $1-20 \%, 21-40 \%, 41-60 \%, 61-80 \%$ and $81-$ $100 \%$.

\section{Estimating shifts in cultivars and maturity times}

We used a long-term dataset from the official variety trials since 1970 at decadal intervals to monitor how plant breeding has altered the time needed for cultivars to reach maturity. Spring barley, oats, wheat, turnip rape, oilseed rape and peas as well as winter wheat and rye cultivars were included in comparisons as model crops because they all have high number of cultivars. Mutually comparable growing times were calculated for all cultivars. This was possible, because each trial included new and older cultivars. So called long-term control cultivars were tested for even more than 10 years. To 
separate the environmental and genetic effects, new and older cultivars were kept in the same line despite the fact that the growing conditions were not the same in the 1970s and 2010s. The following statistical model was applied:

$y_{\mathrm{ijk}}=\mu+$ cultivar $_{\mathrm{i}}+\operatorname{trial}_{\mathrm{jk}}+\varepsilon_{\mathrm{ijk}}$

where $y_{\mathrm{ijk}}$ is the observed growing time, $\mu$ is the intercept, cultivar $_{i}$ is the fixed effect of the $i$ th cultivar, trial ${ }_{j \mathrm{k}}$ is the random effect of a trial located in the jth experimental site in the kth year and $\varepsilon_{\mathrm{ijk}}$ is the residual error. These estimated growing times were used to calculate the means for each decade by grouping the cultivars according to the year each variety was introduced into the variety testing program for the first time. A statistical analysis was performed using SAS/MIXED software.

Additional analyses were carried out to test whether the time in days from sowing to ripeness for a certain cultivar had changed over time, i.e. focusing on the impacts of the growing conditions. This was estimated by adding a calendar year as a continuous variable to Eq. 1. To record the actual changes in the length of the period from sowing to full ripeness depending on the latitude in Finland as an outcome of both shifts in cultivars and growing conditions, the data from the Finnish Food Authority (the same as for analysing spatiotemporal shifts) was used. The growing area of each cultivar in 1996, 2006 and 2016 was calculated in six areas of Finland (equally spaced areas from south to north). Weighted mean of the average growing times of cultivars was calculated for each year-by-region combination ( 3 years $\times 6$ regions) by using growing region of each cultivar as weight. Weighted means were adjusted by the slope of Eq. 1. This acknowledged that the length of the period from sowing to full ripeness in a cultivar was shorten in 2016 than in 1996.

\section{Farmer survey}

Part of a large dataset from a farmer survey with a total of 4400 respondents (Peltonen-Sainio et al. 2020) was used in this study. We characterised how farmers' general observations of the changes in growing conditions and crop cultivation were dependent on the readiness of the farmers to expand the cultivation area for various model crops. The questionnaire contained a variety of questions and was sent to all Finnish farmers via email.

In one part of the questionnaire, the respondents were requested to evaluate a set of responses to the following question, which was linked to the actions taken by farmers: "In the 2000s have you observed any of the following issues on your farm or in near regions?" The respondents were asked to evaluate the following responses to the question: (a) longer growing seasons, (b) earlier onset of crop growth, (c) earlier maturation of yields, (d) novel crops and cultivars available for cultivation, (e) cultivation of later maturing cultivars, (f) increased opportunities for autumn sowing and $(\mathrm{g})$ expanded areas under autumn sown crops and cultivars. All these statements had alternative answer choices: $1=$ not at all, $2=$ rarely, $3=$ occasionally, $4=$ frequently and $5=$ all the time.

Similarly, further on in the questionnaire, the respondents were asked to evaluate a set of responses to two questions, which were also linked to data on the farmers actions. The questions were the following: "How important or unimportant are the following measures?" and "Have you implemented any of the measures or plan to do so in your farm?" The respondents were asked to evaluate the following responses to the questions: (a) cultivating novel crops and cultivars, (b) cultivating early maturing crops and (c) using certified seeds. These statements had alternative answer choices. For the first question ("How important or...?"), the response choices were $1=$ unimportant, 2 =quite unimportant, $3=$ neither nor, $4=$ quite important and $5=$ important. For the last question ("Have you implemented...?"), the response choices were $1=$ does not concern my farm, $2=I$ 'm not going to implement this, $3=\mathrm{I}$ will implement this at the earliest after 6 years, $4=\mathrm{I}$ will implement this within the next $2-5$ years, $5=\mathrm{I}$ will implement this in the next growing season and $6=$ implemented already.

The farmers' readiness to act was tested in three locations that represented cultivation areas which differed in their past shares of crops. The southernmost area was the primary cultivation area of several crop species and included the Uusimaa and Varsinais-Suomi regions (Peltonen-Sainio et al. 2013). The second area included the Satakunta and Pirkanmaa regions, which are not so favourable for crops requiring long growing season, and the third area included the west coast (Pohjanmaa and Etelä-Pohjanmaa), which is an area where diversity of different crops has highly increased over the last 20 years. These regions included 1867 respondents $(779,613$ and 475 for first, second and third regions, respectively), from which 1227 were crop production farms. Spring wheat, turnip rape and winter wheat were used as model crops as there have been shifts in their frequencies over time and there are a sufficiently large number of cultivations areas to enable the categorisation of the farmers. The farmers were categorised into four groups, crop by crop, according to their land use changes from 2006 to 2016. The following categories were used: (a) non-growers who did not cultivate the crop at all (i.e. a reference group of farmers), (b) stable growers who cultivated the crop but expanded its area $<3 \%$ if at all, (c) moderate conversion agent farmers who increased the cultivation area of a crop by $3-15 \%$ and (d) change agent farmers who expanded the area by $>15 \%$. An ANOVA test was used to test the differences between the four groups of farmers, the three regions and their interaction. If the interaction was not statistically significant, all pairwise comparisons between the four 
groups of farmers were done. The analysis was performed using the SAS/GLM procedure.

\section{Results}

\section{Changes in cultivation of major and minor crops}

When comparing the partly overlapping periods of 1970 1990 (earlier) and 1985-2015 (later), it appeared that the growing seasons have become warmer. An accumulation of $900{ }^{\circ} \mathrm{Cd}$ from sowing to mid-September was very common (81-100\%) already in the earlier time period except in the northernmost locations $(61-80 \%)$. However, in the later period, $900^{\circ} \mathrm{Cd}$ also became very frequent in these areas (Fig. 1). In the southernmost locations, $1100{ }^{\circ} \mathrm{Cd}$ was very common, while it was very unlikely $(<20 \%)$ in the northernmost locations, but the likelihood has increased to $21-40 \%$ since the early period. There have been gradual increases in the relative frequencies for higher growing degree days of 1100-1200 ${ }^{\circ} \mathrm{Cd}$ in most regions. However, $1300{ }^{\circ} \mathrm{Cd}$ has not become more likely, but has remained at $<20 \%$ in the central and northern parts of the country. In the two southernmost locations, even $1400^{\circ} \mathrm{Cd}$ has become more common (21-40\%), while in the northern parts of the country such relative frequencies agreed with $1200{ }^{\circ} \mathrm{Cd}$ (Fig. 1). In addition to temperature, sowing time contributes to the growing degree days in a region. As an average, sowing took place 2.2 days later in the North $\left(64^{\circ} \mathrm{N}\right)$ than in the South of Finland $\left(61^{\circ} \mathrm{N}\right)$, but it ranged from 11 days delay in the North to 4 days delay in the South. Sowing time in the West of Finland $\left(22^{\circ} \mathrm{E}\right)$ was again $\leq 5$ days earlier than in the East $\left(28^{\circ} \mathrm{E}\right)$.

Since the mid-1990s, farmers' crop choices have changed. The domination of spring cereals, barley and especially oats has slightly decreased (Fig. S1), while spring wheat has become more popular especially in the inland regions and in the western coastal region and its cultivation has expanded northwards (Figs. 2 and S2). These regional-scale changes in cultivation areas are also apparent according to national scale statistics (Fig. 3). Spring rye, which is a novel crop, had also become more popular by 2006, although the number of field parcels remained $<10$ in any of the $10 \times 10 \mathrm{~km}$ grid where it was cultivated. However, since then, the growing intensity of spring rye has declined. National cultivation areas of overwintering crops change a lot (Fig. 3). The cultivation of winter wheat has declined in its southern traditional cultivation region, but it has expanded northwards and especially following the coastal line (Fig. S3). The cultivation of winter rye has, however, steadily declined in virtually all production regions.

Some secondary or minor crops have become popular during the last 20 years (Fig. 3), though statistics are not available for all of them due to their (earlier) minor importance on the national scale. Oilseed rape (Fig. 4), faba beans (Fig. 5) and caraway (Fig. 6) became popular in the 2000s (Fig. S2). Field peas have become more popular in the very recent years (Figs. 3 and 5). The cultivation of some minor crops such as winter oilseed rape, hemp and maize (Figs. S4 and S5) has
Fig. 1 Differences in relative frequencies $(\%)$ for growing seasons with degree days of 900 , $1000,1100,1200,1300$ and 1400 ${ }^{\circ} \mathrm{Cd}\left(+5^{\circ} \mathrm{C}\right.$ as the base temperature) from sowing to midSeptember at 13 locations across the crop production region in Finland. The left half of the circle indicates the relative frequencies for the time period of 1970-2000 and the right half 1985-2015. Locations of weather stations in order from southern to northern latitudes: 1 = Vantaa, 2 = Salo, 3 = Jokioinen, $4=$ Kouvola, $5=$ Lahti, $6=$ Pori, $7=$ Mikkeli, $8=$ Liperi, $9=$ Ähtäri, $10=$ Seinäjoki, $11=$ Maaninka, $12=$ Haapavesi and $13=$ Kajaani
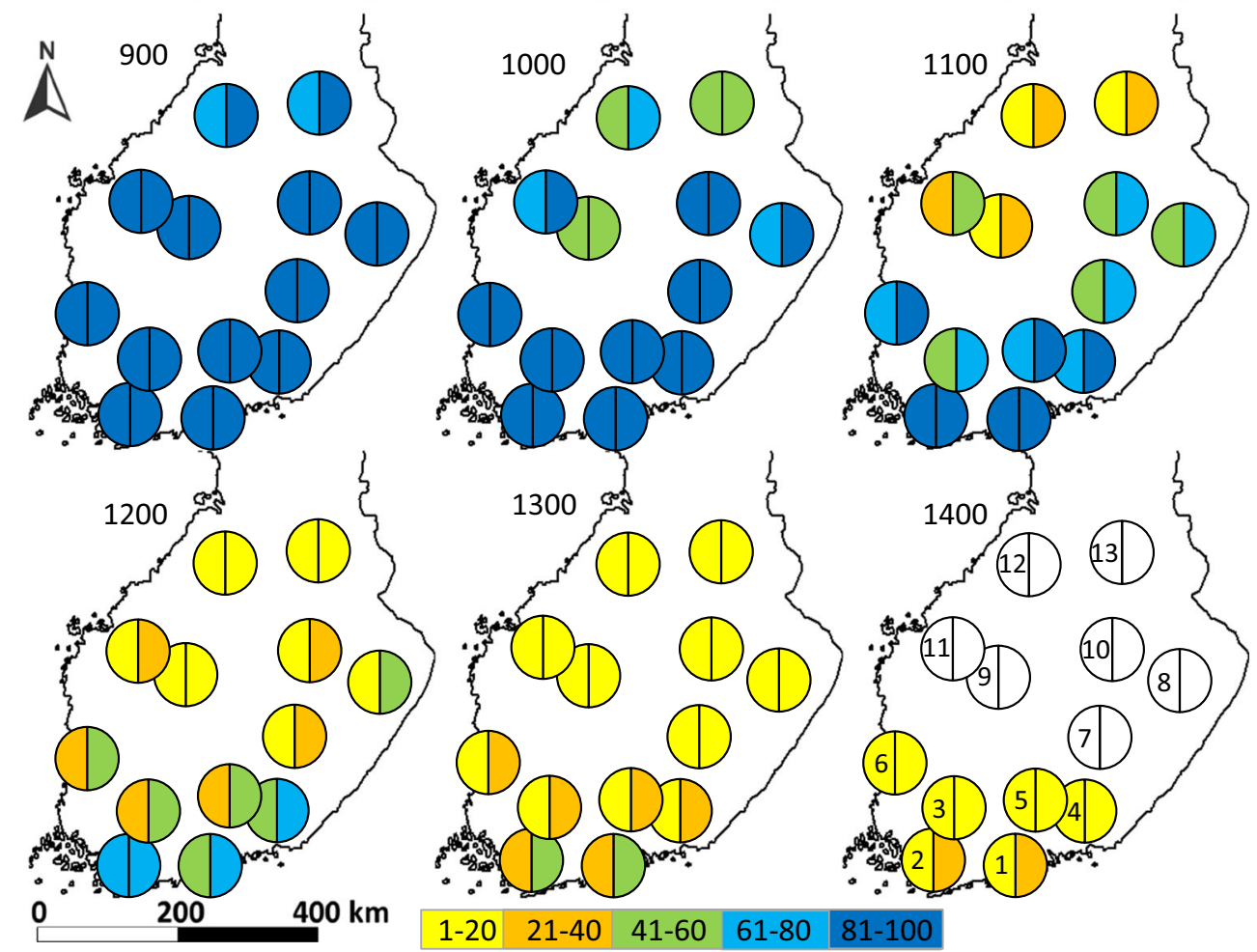
Fig. 2 Maps indicating shifts in a $10 \times 10 \mathrm{~km}$ grid in the number of field parcels with spring wheat and rye under cultivation in 1996 , 2001, 2006, 2011 and 2016. The number of parcels is shown with different colours. White means that there are no parcels in the grid with the crop in question

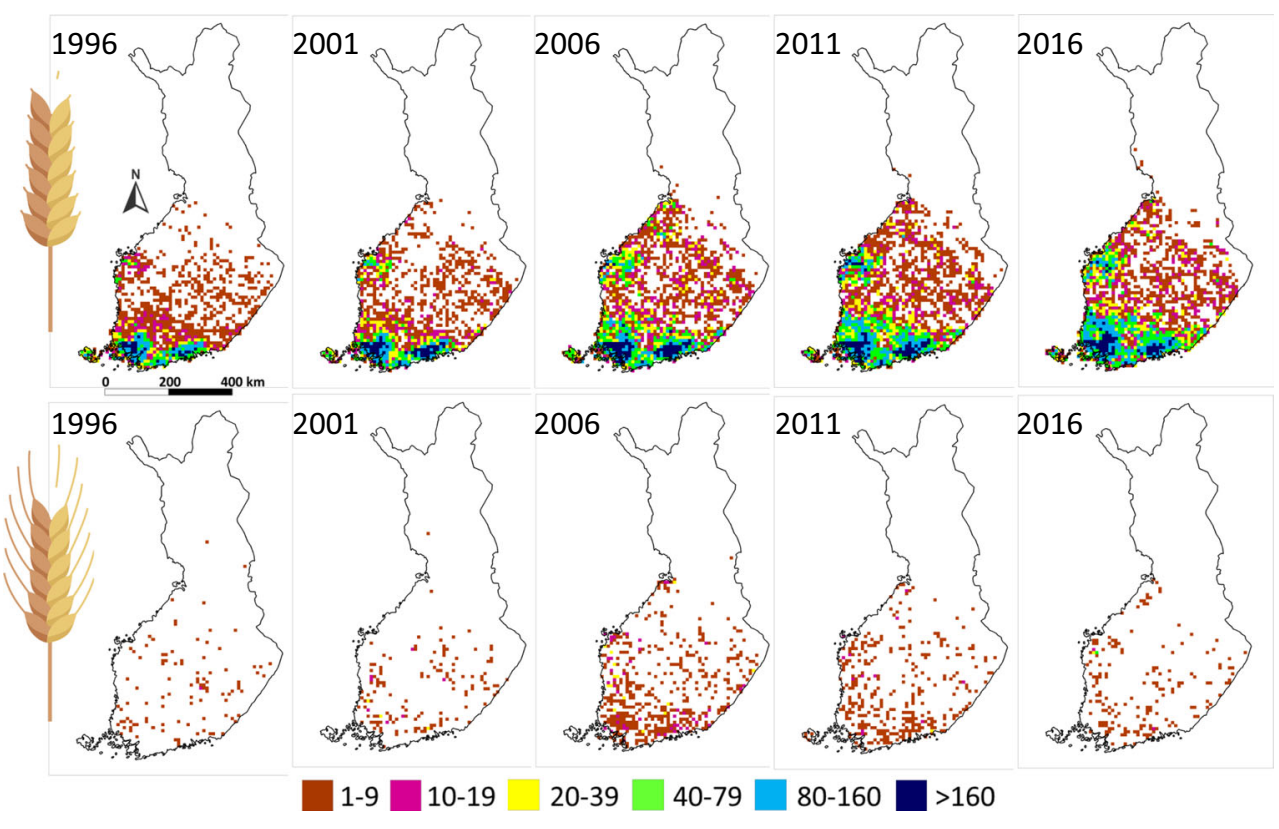

shifted to new regions without experiencing any substantial expansion in the regions that should be most favourable for them. Areas for some other minor crops such as flax and buckwheat (Figs. 6 and S4) have fluctuated without any steady increase, while cultivation areas of potatoes, sugar beet and turnip rape have substantially declined (Fig. 3). Potato production has moved from its inland location in 1996 towards the coastal regions and sugar beet production has dwindled though remains in the south-west of the country (Fig. S6). The number of parcels of turnip rape has dramatically declined in its original prime production region, while it has conquered new regions (Fig. 4).

Grasslands have a major role in agricultural land use in Finland despite many changes between regions and the types of grasslands. In general, perennial grasslands used mainly for silage have begun to dominate the northern parts of the country, while pastures have become less frequent (Fig. S7). Environmental fallows are currently more popular, while fields allocated to annual grasslands have somewhat fluctuated without any clear direction (Fig. S8).

\section{Cultivars and their maturity times}

In the long run, plant breeding has altered the time needed for cultivars to mature. In the 1970s and 1980s, released spring wheat cultivars matured in 103 days on average, while cultivars released in the 1990s matured in 102 days and in the 2000s and 2010s in 105 days $(P<0.001)$. For oat cultivars, the time to maturity took $98-99$ days before the 2000 s and thereafter 100 days on average $(P<0.001)$, and for turnip rape, it was 104 and 105 days $(P=0.03)$, respectively. In the 1970s, 1980s, 1990s, 2000s and 2010s, barley cultivars matured in $90,91,94,94$ and 95 days $(P<0.001)$, while contrary to this, oilseed rape cultivars tended to mature on average in $121,120,119,118$ and 119 days $(P=0.08)$ and pea cultivars in $102,96,95,96$ and 97 days $(P<0.001)$, respectively. For winter rye cultivars, the number of days needed to reach maturity after the onset of the growing season ranged from 106 in the 1970 s to 108 in the $2010 \mathrm{~s}(P<0.01)$, while winter wheat cultivars did not differ $(P=0.41)$.

In addition to the general trends in the time needed to reach maturity for the cultivars depending on year of release, it appeared that for a certain cultivar, the time from sowing to yellow ripeness took 0.85 days less per decade for winter rye $(P=0.05), 1.26$ days less for winter wheat $(P=0.02)$, 2.92 days less for turnip rape $(P<0.001)$ and 2.52 days less for oilseed rape to mature $(P<0.001)$. In contrast to these findings, it took 3.04 days more per decade for the same pea cultivars to mature $(P<0.001)$. No changes in time to maturity were found for spring cereal cultivars (the $P$ value ranged from 0.31 to 0.59 ).

When considering the joint effect of changes in breeds and weather conditions on the length of the period from sowing to maturity, it appeared that in 1996, barley cultivars required $>1$ day less to mature than in 2006 and $>2$ days less than in 2016 at the southernmost latitude of Finland (Table 1). The general tendency of having later maturing barley cultivars agreed across all its production regions and also for oats, but only at the southernmost latitudes. Spring wheat cultivars tended to be become slightly more later maturing in 2016 than 20 years earlier, but data was limited for 1996 in the two northermost latitudes. Turnip rape cultivars were systematically later maturing by $1-2$ days contrary to oilseed rape cultivars as they required less days to mature since 1996 at the three southern 

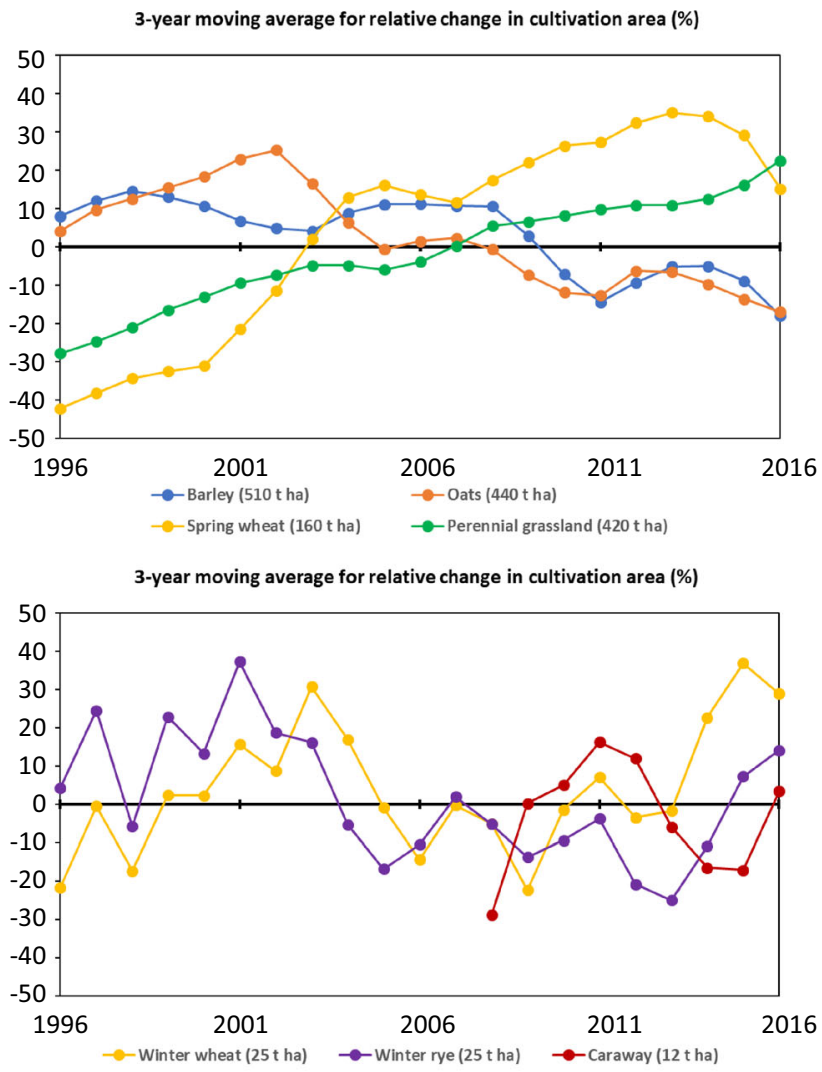

3-year moving average for relative change in cultivation area (\%)

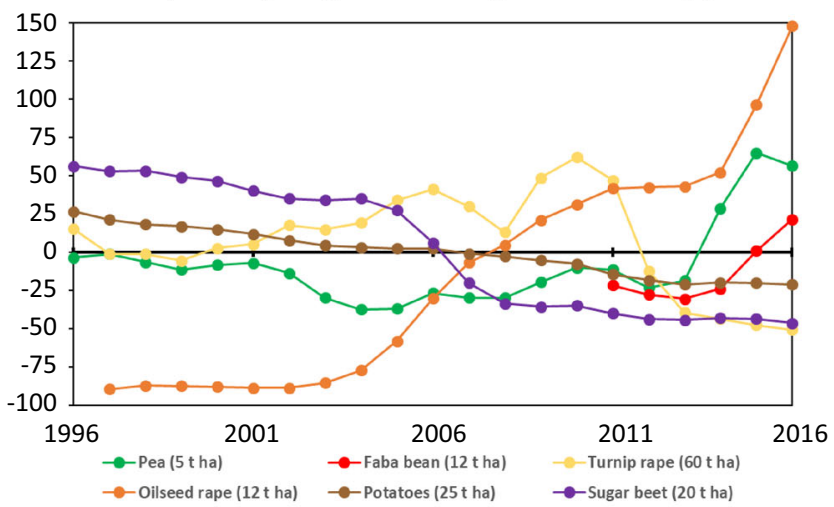

Fig. 3 Shifts in national cultivation areas of different crops during the 20year study period from 1996 to 2016. The 3-year moving averages are shown for relative changes in the cultivation area and the mean areas across the study period for each crop are shown in parenthesis in the crop legends

latitudes, where they are primarily grown. Data on oilseed rape was available also for a latitude $>6,900,000$ for 2016 with a share of almost $10 \%$ of cultivated land (Table 1).

\section{Farmers' views and actions}

Farmers had most frequently observed that the growing seasons had become longer, and novel crops and cultivars were available for cultivation (Fig. S9). Additionally, they reported that later maturing cultivars were grown more frequently, and crop growth had started earlier. The farmers had not recognised so often earlier maturation of yields, better opportunities for autumn sowing and expanded areas for autumn sown crops.

Farmers who did not grow the crop were usually those who had least recognised any changes in the production environment (Table 2). This did not differ according to the study region (data not shown). Farmers who were classified as change agents and who cultivated spring wheat considered that the growing seasons had become longer and differed $(P=0.05)$ from farmers who were classified as non-growers or moderate conversion agents. Farmers classified as change agents and moderate conversion agents differed $(P=0.02)$ from non-growers and reported that novel crops and cultivars had become available for cultivation. Furthermore, all other farmer groups than non-growers $(P<0.001)$ were clearly more positive about new opportunities for the cultivation of later maturing cultivars (Table 2). Nonetheless, farmers who were classified as moderate conversion agents and were growing winter wheat had slightly more frequently recognised (mean 2.85) than non-growers (2.60) that areas under autumn sown crops and cultivars had expanded $(P=0.02$, data now shown).

Farmers who did not grow spring turnip rape differed from other farmer groups (Table 2) and less frequently recognised that the cultivation of later maturing cultivars had expanded $(P<0.001)$. They also differed from farmers who were classified as stable growers and moderate conversion agents in that they less frequently considered that novel crops and cultivars were available for cultivation $(P<0.001)$. Farmers classified as moderate conversion agents who grew turnip rape differed $(P=$ 0.03) from other farmer groups by being more positive about increased opportunities for autumn sowing. Farmers classified as moderate conversion agents and change agents differed from the reference group of non-growers by slightly better recognising that areas under autumn sown crops and cultivars had expanded $(P=0.01)$.

When farmers were asked whether they had implemented any of the measures or planned to do so in their farm (Fig. S10), the reference group of non-growers of spring wheat and turnip rape differed from any other farmer groups $(P<0.001)$ by being less active in starting to cultivate novel crops and cultivars (Table S1). The same was true for winter wheat. Whether all farms or just crop production farms were compared had no major impacts on the outcomes. Similarly, non-growers of spring wheat $(P=0.02)$ and turnip rape $(P<0.001)$ differed from other farmer groups when they were asked how important 
Fig. 4 Maps indicating shifts in a $10 \times 10 \mathrm{~km}$ grid in the number of field parcels with spring turnip rape and oilseed rape. See Fig. 2 for further information

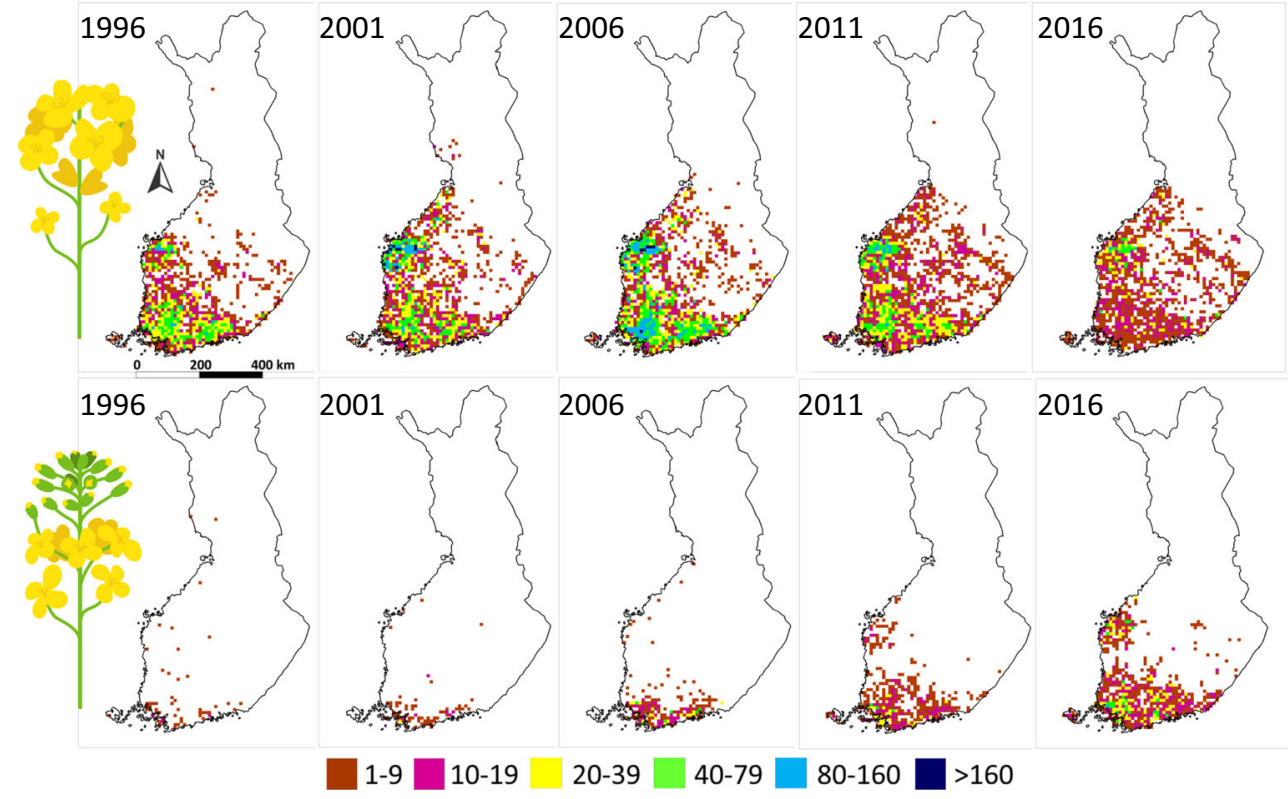

or unimportant it was to cultivate novel crops and cultivars (data not shown).

\section{Discussion}

\section{Shifts of crops towards new production regions}

In Finland, the expansion of the cultivation area of crops in the recent two decades has coincided with observed increases in the relative frequencies of higher growing degree days from sowing to harvest (Fig. 1). Within Europe, a large regional variation has been found for means to adapt to climate change: in the northern parts that Finland represents, the introduction of new crops and cultivars and changes in the timing of field operations were found to be the main adaptations to longer growing seasons and reduced stress caused by low temperatures (Zhao et al. 2020). The future pace of change in global warming is dependent on greenhouse gas emissions, but in all likely scenarios, the growing season will be substantially longer in the future (Ruosteenoja et al. 2016) and shifts of the thermal seasons are projected to take place at the expense of winters (Ruosteenoja et al. 2019). Thereby, the findings concerning the on-going changes in cultivation areas may be just a foretaste of further changes to come.

The crops that most substantially gained new areas in Finland since 1996 were faba beans and peas (Fig. 5), caraway (Fig. 6), spring oilseed rape (Fig. 4) and winter wheat (Fig.
Fig. 5 Maps indicating shifts in a $10 \times 10 \mathrm{~km}$ grid in the number of field parcels with peas and faba beans. See Fig. 2 for further information

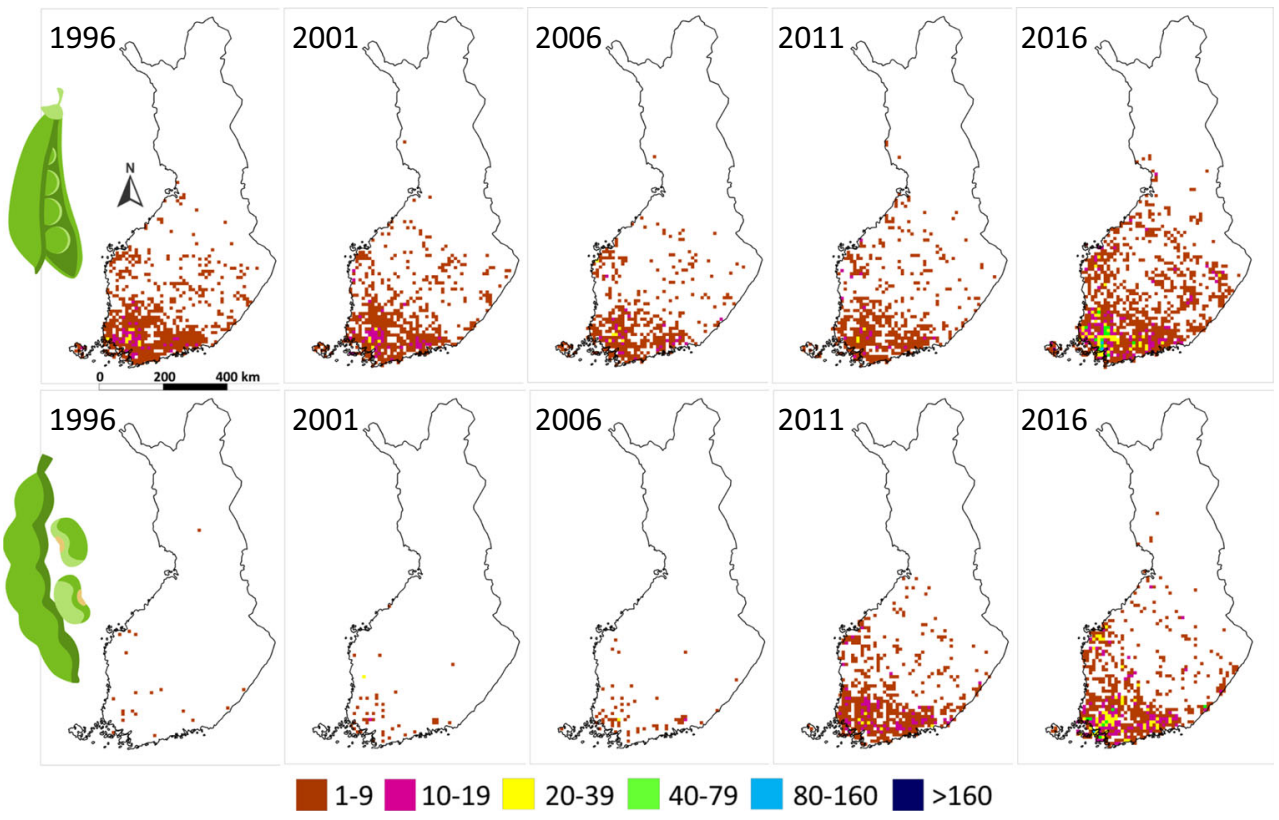


Fig. 6 Maps indicating shifts in a $10 \times 10 \mathrm{~km}$ grid in the number of field parcels with caraway and buckwheat. See Fig. 2 for further information

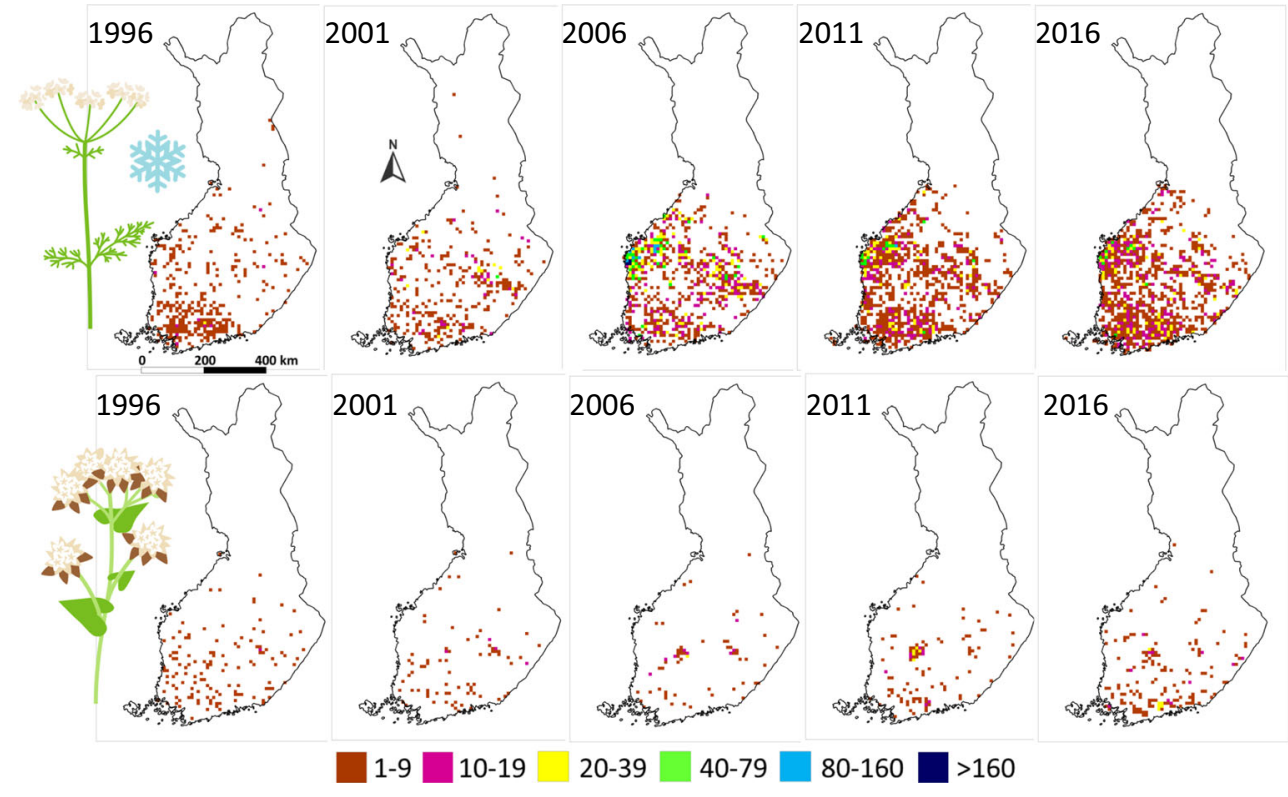

S3). While oilseed rape areas have expanded in the southernmost regions and have been introduced into new areas, turnip rape has lost ground in its primary production region. Turnip rape has, however, been a pioneer oil crop that has expanded into new areas (Fig. 4) as anticipated by Peltonen-Sainio et al. (2009b). Spring wheat, another crop with a well-established role in Finland, has also gained more area as was projected by Elsgaard et al. (2012).

Turnip rape is not the sole crop that has given way for expansion of other crops: cultivation areas of potatoes, sugar beet (Fig. S6), winter rye (Fig. S3), flax (Fig. S4) and even oats (Figs. 3 and S1) have declined. Elsgaard et al. (2012) projected that due to climate warming cultivation area of oats may gradually decline by 2050 at high latitudes. The main driver for the anticipated change was that oats prefer cool growing conditions and hence, models suggested that oats would shift northwards to follow the change in the temperature conditions (Elsgaard et al. 2012). Oats have indeed lost ground in their prime south-western and western production regions, and similar changes have also taken place in inland and eastern regions, but without any clear balancing increases in northern acreages (Fig. S1). The cultivation of barley has been more stable than that of oats, but barley has also paved the way for other, later maturing crops in the 2010s (Fig. 3). The area used for the cultivation of potatoes has declined (Fig. S6) partly due to changes in consumption habits, as well as specialised production that has replaced cultivation in home gardens, but also due to higher risks of earlier infections caused by Phytopthora infestans (Lehsten et al. 2017). Potato production may decrease on a global scale due to climate change, depending on region, with profoundly negative impacts on eastern Europe including Finland (George et al. 2017; Raymundo et al. 2018). A decline in the sugar beet area in Finland was again caused by liberalisation of global sugar markets.

Novel crops such as spring rye (Fig. 2), buckwheat (Fig. 6), winter rapeseed (Fig. S4), maize and hemp (Fig. S5) have approach new areas and are being cultivated in a higher total share of hectares, but their areas have remained negligible, possibly due to their high production risks and uncertainty, lack of experience in their cultivation and in some cases undeveloped markets. Back in the 1980s, spring wheat and turnip rape were primary crops in Finland only in the southernmost strip of land. The production risks were far too high for any expansion beyond their cropping area at the time (Mukula and Rantanen 1987) - not to mention the anticipated negligible probability of success with minor crops, that after less than 30 years however exhibited expanded cultivation areas. Maize is approaching Finland despite its high temperature requirements. This is considered a real manifestation of climate change in the country. Elsgaard et al. (2012) projected that by 2050 , the maize production area may be up to $10 \%$ in regions with the highest cumulated degree days. Field parcels have been allocated for maize already by 2016 (Fig. S5), but so far, this is considered an on-going familiarisation with its performance and cultivation methods. Nonetheless, some success stories already exist: in 2018, high temperatures and severe drought interfered with the regrowth of grasslands, and in some farms, flourishing maize stands provided a viable substitute for grass-based silage. Climate change is projected to have negative impacts on winter oilseed rape in its current cultivation areas in Europe and therefore, it may shift towards Boreal regions (Jaime et al. 
Table 1 Changes in the land area and the length of the period from sowing to maturity in days for the dominating barley, oats, wheat, turnip rape and oilseed rape cultivars in each time period $(1996,2006,2016)$

\begin{tabular}{|c|c|c|c|c|c|c|c|c|c|}
\hline \multirow[t]{2}{*}{ Crop/latitude $\mathrm{a}^{\mathrm{a}, \mathrm{b}}$} & \multicolumn{3}{|l|}{1996} & \multicolumn{3}{|l|}{2006} & \multicolumn{3}{|l|}{2016} \\
\hline & Share $(\%)$ & Area (ha) & Growing time (d) & Share $(\%)$ & Area (ha) & Growing time (d) & Share $(\%)$ & Area (ha) & Growing time (d) \\
\hline \multicolumn{10}{|l|}{ Barley } \\
\hline $6,600,000$ & 6.1 & 33,087 & 92.9 & 4.5 & 25,424 & 94.2 & 4.4 & 19,215 & 95.1 \\
\hline $6,700,000$ & 44.0 & 238,659 & 92.5 & 39.9 & 225,425 & 93.6 & 37.3 & 162,894 & 94.5 \\
\hline $6,800,000$ & 11.1 & 60,207 & 89.3 & 10.6 & 59,887 & 91.5 & 10.9 & 47,602 & 92.2 \\
\hline $6,900,000$ & 17.3 & 93,836 & 87.7 & 19.0 & 107,345 & 90.6 & 20.5 & 89,526 & 91.0 \\
\hline $7,000,000$ & 13.9 & 75,394 & 86.1 & 16.7 & 94,351 & 88.8 & 18.0 & 78,608 & 89.7 \\
\hline $7,100,000$ & 6.7 & 36,341 & 85.4 & 8.2 & 46,328 & 87.4 & 8.1 & 35,374 & 88.3 \\
\hline \multicolumn{10}{|l|}{ Oats } \\
\hline $6,600,000$ & 3.7 & 13,850 & 99.9 & 3.0 & 10,618 & 100.3 & 3.7 & 11,051 & 100.6 \\
\hline $6,700,000$ & 35.8 & 134,011 & 99.7 & 33.6 & 118,924 & 99.5 & 38.4 & 114,687 & 99.9 \\
\hline $6,800,000$ & 20.2 & 75,615 & 97.9 & 22.0 & 77,867 & 97.3 & 19.2 & 57,343 & 97.4 \\
\hline $6,900,000$ & 24.6 & 92,086 & 96.5 & 23.4 & 82,822 & 96.4 & 20.7 & 61,823 & 96.8 \\
\hline $7,000,000$ & 11.2 & 41,925 & 95.4 & 11.2 & 39,641 & 95.9 & 10.6 & 31,658 & 96.1 \\
\hline $7,100,000$ & 4.1 & 15,348 & 94.9 & 6.4 & 22,652 & 95.6 & 6.8 & 20,309 & 95.4 \\
\hline \multicolumn{10}{|l|}{ Wheat } \\
\hline $6,600,000$ & 32.7 & 28,532 & 103.4 & 19.4 & 33,432 & 104.2 & 14.1 & 24,971 & 104.5 \\
\hline $6,700,000$ & 63.4 & 55,320 & 103.1 & 59.4 & 102,364 & 103.5 & 61.7 & 109,268 & 104.1 \\
\hline $6,800,000$ & 1.7 & 1483 & 102.0 & 6.7 & 11,546 & 102.4 & 9.5 & 16,824 & 103.1 \\
\hline $6,900,000$ & 1.8 & 1571 & 101.9 & 8.5 & 14,648 & 101.8 & 9.6 & 17,001 & 102.3 \\
\hline $7,000,000$ & $<1.0$ & - & - & 4.1 & 7066 & 101.1 & 3.9 & 6907 & 101.5 \\
\hline $7,100,000$ & $<1.0$ & - & - & 1.8 & 3102 & 100.5 & 1.2 & 2125 & 101.3 \\
\hline \multicolumn{10}{|l|}{ Turnip rape } \\
\hline $6,600,000$ & 11.3 & 6793 & 103.8 & 8.8 & 8828 & 104.8 & 4.2 & 1155 & 105.7 \\
\hline $6,700,000$ & 59.7 & 35,889 & 103.7 & 53.3 & 53,468 & 104.7 & 34.5 & 9491 & 105.6 \\
\hline $6,800,000$ & 12.3 & 7394 & 103.8 & 10.8 & 10,834 & 104.4 & 17.0 & 4677 & 105.5 \\
\hline $6,900,000$ & 12.9 & 7755 & 103.8 & 17.5 & 17,555 & 104.3 & 28.3 & 7786 & 105.4 \\
\hline $7,000,000$ & 3.6 & 2164 & 103.8 & 8.1 & 8126 & 104.3 & 13.0 & 3576 & 105.5 \\
\hline $7,100,000$ & $<1.0$ & - & - & 1.3 & 1304 & 104.2 & 3.1 & 853 & 105.5 \\
\hline \multicolumn{10}{|l|}{ Oilseed rape } \\
\hline $6,600,000$ & 53.4 & 351 & 120.6 & 53.3 & 3911 & 118.6 & 16.4 & 4565 & 118.7 \\
\hline $6,700,000$ & 42.2 & 278 & 120.4 & 45.0 & 3302 & 118.5 & 64.0 & 17,813 & 118.6 \\
\hline $6,800,000$ & 3.0 & 20 & 120.3 & $<1.0$ & - & - & 6.6 & 1837 & 118.0 \\
\hline $6,900,000$ & $<1.0$ & - & - & $<1.0$ & - & - & 9.8 & 2728 & 118.5 \\
\hline
\end{tabular}

${ }^{a}$ Latitude $6,600,000$ covers the area from $6,600,000$ to $6,699,999$, latitude $6,700,000$ from $6,700,000$ to 6,799,999 and so on (Uniform Coordinate System)

${ }^{\mathrm{b}}$ Latitude 6,600,000 includes the meteorological station in Vantaa; 6,700,000 Salo, Jokioinen, Lahti and Kouvola; 6,800,000 Pori and Mikkeli; 6,900,000 Seinäjoki, Ähtäri and Liperi; 7,000,000 Maaninka; and 7,100,000 Haapavesi and Kajaani

2018; Pullens et al. 2019). Finnish farmers' interest in cultivation of winter oilseed rape has already increased (Fig. S4) as novel cultivars have become available and the growing conditions have become more favourable (Mäkelä et al. 2011). As elevated temperatures may be a great challenge for future rapeseed production at high latitudes (Peltonen-Sainio et al. 2007; Qian et al. 2018), winter oilseed rape may represent a means to avoid this emerging risk.

\section{Support provided by plant breeding}

The observed warming in eastern, northern coastal and northern regions of Finland (Fig. 1) has already encouraged farmers 
Table 2 Differences in farmers' views on alternative survey statements for the question "In the 2000s have you observed any of the following issues on your farm or in near regions?" when crop production farms were grouped into four categories according to shifts in cultivation of spring wheat, turnip rape and winter wheat during 2006-2016. Non-growers did not cultivate the crops (reference group), while stable growers increased the cropping area by less than $3 \%$; moderate conversion agents did so by $3-15 \%$, while change agents increased their growing areas by $>15 \%$. Means with the same letter in the same row do not differ significantly from each other (at $P>0.05$ )

\begin{tabular}{|c|c|c|c|c|c|c|c|c|c|}
\hline \multirow[t]{2}{*}{ Crop (farm type)/statement } & \multirow[t]{2}{*}{$P$ value ${ }^{\mathrm{a}}$} & \multicolumn{8}{|c|}{ Mean for a farmer group ${ }^{\mathrm{b}}$} \\
\hline & & \multicolumn{2}{|c|}{ Non-growers } & \multicolumn{2}{|c|}{ Stable growers } & \multicolumn{2}{|c|}{ Moderate conversion agents } & \multicolumn{2}{|c|}{ Change agents } \\
\hline \multicolumn{10}{|l|}{ Spring wheat } \\
\hline Longer growing season & 0.05 & 3.00 & $\mathrm{~b}$ & 2.95 & $a b$ & 2.80 & $\mathrm{~b}$ & 3.19 & $\mathrm{a}$ \\
\hline Novel crops and cultivars available for cultivation & 0.02 & 3.10 & $\mathrm{~b}$ & 3.25 & $a b$ & 3.38 & $\mathrm{a}$ & 3.32 & $\mathrm{a}$ \\
\hline Cultivation of later maturing cultivars & $<0.001$ & 2.98 & $\mathrm{~b}$ & 3.31 & a & 3.33 & $\mathrm{a}$ & 3.26 & $\mathrm{a}$ \\
\hline \multicolumn{10}{|l|}{ Spring turnip rape } \\
\hline Novel crops and cultivars available for cultivation & $<0.01$ & 3.08 & $\mathrm{~b}$ & 3.30 & $\mathrm{a}$ & 3.47 & $\mathrm{a}$ & 3.23 & $a b$ \\
\hline Cultivation of later maturing cultivars & $<0.001$ & 2.96 & $\mathrm{~b}$ & 3.27 & a & 3.44 & $\mathrm{a}$ & 3.21 & $\mathrm{a}$ \\
\hline Increased opportunities for autumn sowing & 0.03 & 2.43 & $\mathrm{~b}$ & 2.49 & $\mathrm{~b}$ & 2.77 & $\mathrm{a}$ & 2.51 & $\mathrm{~b}$ \\
\hline Expanded areas under autumn sown crops and cultivars & 0.01 & 2.57 & $\mathrm{~b}$ & 2.66 & $a b$ & 2.89 & $\mathrm{a}$ & 2.77 & $\mathrm{a}$ \\
\hline
\end{tabular}

${ }^{a}$ Significance of difference between farmer groups

${ }^{\mathrm{b}}$ The answer choices were $1=$ not at all, $2=$ rarely, $3=$ occasionally, $4=$ frequently and $5=$ all the time

to cultivate novel crops. This expansion into new regions is supported by breeding cultivars with a large spectrum of growing times. Earlier maturing cultivars were grown in the northernmost regions to cope with the lower growing degree days (Table 1). However, quite systematic shifts in time towards later maturing cultivars were found for barley, oats and spring wheat up to latitude $7,000,000$, and in turnip rape, surprisingly even up to latitude $7,100,000$. Oilseed rape is, however, among the latest maturing harvested crops in Finland and the growing time of oilseed rape cultivars has become shorter. The expansion of oilseed rape beyond its traditional growing area (Fig. 4) is hence at least partly attributable to the introduction of early maturing oilseed rape cultivars that exhibit lower production risks.

The observed shifts in the time required by crops to mature are attributable to changes in the time needed to reach maturity of the released cultivars and the impacts of growing conditions, especially temperature. Spring cereal, winter cereal and turnip rape cultivars from the last couple of decades have required more days (and a higher growing degree days) to mature than those before the millennium. Despite such changes in the released cultivars, rapeseed and winter cereals have matured earlier (0.85-2.92 days shorter period from sowing to maturity per decade), which is likely to be attributable to elevated temperatures, sometimes coupled with terminal drought (Peltonen-Sainio et al. 2011). Even though breeding has produced later maturing spring cereal cultivars since the 1970s, their maturation in days per decade has not changed. In the future, the growing seasons will be so long (Ruosteenoja et al. 2016) that according to simulation studies, even the latest maturing, "exotic" cultivars for current conditions in Finland may be unable to fully exploit the warm and prolonged autumn period (Peltonen-Sainio et al. 2018). Hence, double cropping of primary crops with cover crops may be a promising means to reduce the time period of bare ground cover (Peltonen-Sainio et al. 2018) and mitigate the negative impacts on the soil conditions and environment (Guardia et al. 2019; Lal 2015). In addition to oilseed rape, pea cultivars were bred to be earlier maturing than in the 1970 s, but they have ripened even up to 3.04 days later per decade. This may be attributable to the exceptional ability of peas to exploit elevated temperatures in high-latitude conditions (Peltonen-Sainio et al. 2011), which may indicate substantial future potential for expanded production in northern Europe (Manners et al. 2020).

\section{Climate is the primary but not the sole driver for successful crop expansion}

Recent studies have emphasised significant potential and the need to diversify current cereal-based crop production systems (Peltonen-Sainio et al. 2017; Peltonen-Sainio and Jauhiainen 2019). In addition to spring cereals (Figs. 2 and S1), different types of grasslands (Figs. S7 and S8) dominate land use, but these production systems are polarised in the sense that crop production farms with cereal rotations are primarily in the south and dairy production farms with grassland rotations are located in the north and east of the country. Hence, grasslands do not often break up monotonous cereal sequencing. However, this study showed that many minor and novel crops 
have already been introduced into high-latitude agricultural systems, which reflects the anticipated potential (PeltonenSainio et al. 2009a) that climate change has for the diversification of crop choices. Simultaneously, the areas under primary cereals, including oats and more recently also barley, have declined (Fig. 3), and these species are often grown as monoculture rotations, i.e. barley after barley and oats after oats (Peltonen-Sainio and Jauhiainen 2019).

The drivers for expansion and diversification differ depending on the crop. Changes in the balance in land use between turnip rape and oilseed rape (Fig. 4) have been boosted by the problems and concomitant declines in turnip rape yields that have eventually frustrated many farmers (Peltonen-Sainio et al. 2007). In such a situation, the expansion of oilseed rape has been a response to meet the demand for high-quality, domestic crop-based protein needed to alleviate dependency on imported soybeans (Glycine max L.) in animal feeds (Sandström et al. 2018). Hence, existing, ready-to-go markets and industries have supported the expansion of oilseed rape. The cultivation of grain legumes has increased as well (Fig. 5) driven by demand for domestic protein (Peltonen-Sainio et al. 2013), but also due to valuable ecosystem services provided by grain legumes: especially nitrogen fixation and reduced needs for fertiliser for subsequent crops - not least as many farms have faced economic challenges (Scherer et al. 2018). Caraway has been a true success story, i.e. demonstrating how a minor crop can become an important, high-quality niche crop in northern climates (Galambosi and Peura 1996). Emerging industries (www.transfarm.fi) have supported the expansion of caraway, and as an outcome, Finland is now a key player in the world's caraway markets.

Economic forces often favour specialisation of production systems over diversification (Zander et al. 2016). As shown in the above cases, the markets and prices of potential minor crops, when compared to the dominant cereal crops, largely determine whether their areas will expand or not (Liu et al. 2016). This is despite many interesting crop features, including the capacity to diversify crop rotations and cope with future climates (Borrell et al. 2020; Cheng 2018). Undeveloped markets and limited access to well-adapted cultivars are among the primary reasons why minor crops such as buckwheat, maize and hemp (that benefit from the warming climate and longer growing season) remain waiting for their future prospects, although farmers have shown a budding interest in their cultivation (Figs. 6 and S5). The lack of welladapted cultivars is an outcome of negligible breeding efforts for secondary and minor crops. This trend is fortified by a universal phenomenon, the consolidation of breeding companies that have merged with agro-input suppliers. This has led to pressure on to focus on primary crops with vast production regions globally, at the expense of secondary and minor crops and genetic diversity (Howard 2015; Solberg and Breian 2015). The reduced cultivation area of sugar beet in Finland
(Fig. S6) despite growth favouring longer and warmer growing seasons is another type of example of the counterforce to expanded production: liberalisation of global sugar markets caused a marked reduction in the sugar beet cultivation area in Finland.

High-latitude farmers have already adapted to a changed climate or intend to do so in various ways. Introducing novel crops and cultivars and expanding cultivation of current secondary and minor crops is just one though important means for farmers to adapt (Peltonen-Sainio et al. 2020). Farmers, who have already recognised that crop growth has started earlier, that growing seasons have become longer and that later maturing cultivars and novel crops are being cultivated more than before (Fig. S9), have often expanded their cultivation of the studied model crops during recent decades (Table S1). Adaptation and risk management are farm-scale decision-making processes. However, due to the high number of adaptation needs, many potential trade-offs may occur (Wiréhn et al. 2020) which also impacts the environment. Hence, it is important that farmers get coherent and timely policy guidance and support (Käyhkö 2019) and agricultural extension services to safeguard success in adapting and maintaining a rural livelihood in the future.

\section{Conclusions}

This study demonstrated phenomenal spatiotemporal changes in cultivation areas for many major, secondary and minor crops and shifts in the time needed to reach maturity for cultivars as well as shifts towards new regions in Finland with high regional discrepancies in the premises for crop production. Some of the traditional major crops have paved the way for emergent crops. Especially grain legumes, wheat and caraway have captured new areas contrary to oats, barley and potatoes. The expansion of cultivation areas of secondary, minor and novel crops is primarily enabled by climate warming, but success is also decisively dependent on the nexus of availability-access-affordability, which is a common triangle familiar to us in the context of food security. Availability refers to breeding, which provides well-adapted cultivars for farmers, access refers to existing or emerging markets and industries, or opportunities for export, while again affordability refers to prices, policy support and valued ecosystem services provided by emergent crops.

Funding information Open access funding provided by Natural Resources Institute Finland (Luke). This work was financed by the Ministry of Agriculture and Forestry and Natural Resources Institute Finland (Luke) as a part of the projects entitled LOSSI, VILKAS and EASME/EU-Life (OPAL-Life; LIFE14 CCM/FI/000254; This paper reflects only the authors' view and the EASME/Commission is not responsible for any use that may be made of the information it contains). 
Open Access This article is licensed under a Creative Commons Attribution 4.0 International License, which permits use, sharing, adaptation, distribution and reproduction in any medium or format, as long as you give appropriate credit to the original author(s) and the source, provide a link to the Creative Commons licence, and indicate if changes were made. The images or other third party material in this article are included in the article's Creative Commons licence, unless indicated otherwise in a credit line to the material. If material is not included in the article's Creative Commons licence and your intended use is not permitted by statutory regulation or exceeds the permitted use, you will need to obtain permission directly from the copyright holder. To view a copy of this licence, visit http://creativecommons.org/licenses/by/4.0/.

\section{References}

Asseng S, Ewert F, Martre P, Rötter RP, Lobell DB, Cammarano D, Kimball BA, Ottman MJ, Wall GW, White JW, Reynolds MP, Alderman PD, Prasad PVV, Aggarwal PK, Anothai J, Basso B, Biernath C, Challinor AJ, De Sanctis G, Doltra J (2015) Rising temperatures reduce global wheat production. Nature Clim Change 5:143-147. https://doi.org/10.1038/nclimate2470

Borrell JS, Dodsworth S, Forest F, Pérez-Escobar OA, Lee MA, Mattana E, Stevenson PC, Howes M-R, Pritchard HW, Ballesteros D, Kusumoto B, Ondo I, Moat J, Milliken W, Ryan P, Ulian T, Pironon S (2020) The climatic challenge: which plants will people use in the next century? Environ Exp Bot 170:103872. https://doi. org/10.1016/j.envexpbot.2019.103872

Ceglar A, Zampieri M, Toreti A, Dentener F (2019) Observed northward migration of agro-climate zones in Europe will further accelerate under climate change. Earth's Future 7:1088-1101. https://doi.org/ 10.1029/2019EF001178

Cheng A (2018) Review: shaping a sustainable food future by rediscovering long-forgotten ancient grains. Plant Sci 269:136142. https://doi.org/10.1016/j.plantsci.2018.01.018

Elsgaard L, Borgesen CD, Olesen JE, Siebert S, Ewert F, Peltonen-Sainio P, Rötter RP, Skjelvag AO (2012) Shifts in comparative advantages for maize, oat and wheat cropping under climate change in Europe. Food Addit Contam Part A Chem Anal Control Expo Risk Assess 29:1514-1526. https://doi.org/10.1080/19440049.2012.700953

Galambosi B, Peura P (1996) Agrobotanical features and oil content of wild and cultivated forms of caraway (Carum carvi L.). J Essent Oil Res 8:389-397. https://doi.org/10.1080/10412905.1996.9700646

George TS, Taylor MA, Dodd IC, White PJ (2017) Climate change and consequences for potato production: a review of tolerance to emerging abiotic stress. Potato Res 60:239-268. https://doi.org/10.1007/ s11540-018-9366-3

Guardia G, Aguilera E, Vallejo A, Sanz-Cobena A, Alonso-Ayuso M, Quemada M (2019) Effective climate change mitigation through cover cropping and integrated fertilization: a global warming potential assessment from a 10-year field experiment. J Clean Prod 241: 118307. https://doi.org/10.1016/j.jclepro.2019.118307

Hakala K, Hannukkala A, Huusela-Veistola E, Jalli M, Peltonen-Sainio P (2011) Pests and diseases in a changing climate a major challenge for Finnish crop production. Agric Food Sci 20:3-14

Howard PH (2015) Intellectual property and consolidation in the seed industry. Crop Sci 55:2489-2495. https://doi.org/10.2135/ cropsci2014.09.0669

Jaime R, Alcántara JM, Manzaneda AJ, Rey PJ (2018) Climate change decreases suitable areas for rapeseed cultivation in Europe but provides new opportunities for white mustard as an alternative oilseed for biofuel production. PLoS One 13:e0207124. https://doi.org/10. 1371/journal.pone.0207124
Juroszek P, von Tiedemann A (2013) Climate change and potential future risks through wheat diseases: a review. Eur J Plant Pathol 136:2133. https://doi.org/10.1007/s10658-012-0144-9

Kaukoranta T, Hakala K (2008) Impact of spring warming on sowing times of cereal, potato and sugar beet in Finland. Agric Food Sci 17: $165-176$

Käyhkö J (2019) Climate risk perceptions and adaptation decisionmaking at Nordic farm scale - a typology of risk responses. Int $\mathrm{J}$ Agric Sust 17:431-444. https://doi.org/10.1080/14735903.2019. 1689062

Lal R (2015) Restoring soil quality to mitigate soil degradation. Sustainability 7:5875-5895. https://doi.org/10.3390/su7055875

Lehsten V, Wiik L, Hannukkala A, Andreasson E, Chen D, Ou T, Liljeroth E, Lankinen Å, Grenville-Briggs L (2017) Earlier occurrence and increased explanatory power of climate for the first incidence of potato late blight caused by Phytophthora infestans in Fennoscandia. PLoS One 12:e0177580. https://doi.org/10.1371/ journal.pone. 0177580

Liu X, Lehtonen H, Purola T, Pavlova Y, Rötter R, Palosuo T (2016) Dynamic economic modelling of crop rotations with farm management practices under future pest pressure. Agric Syst 144:65-76. https://doi.org/10.1016/j.agsy.2015.12.003

Mäkelä PSA, Tuulos A, Turakainen M, Santanen A, Stoddard FL (2011) Revitalizing the winter turnip rape crop in the northern latitudes. Acta Agric Scand Sect B Soil Plant Sci 61:195-201. https://doi. org/10.1080/09064711003747470

Mäkinen H, Kaseva J, Trnka M, Balek J, Kersebaum KC, Nendel C, Gobin A, Olesen JE, Bindi M, Ferrise R, Moriondo M, Rodríguez A, Ruiz-Ramos M, Takáč J, Bezák P, Ventrella D, Ruget F, Capellades G, Kahiluoto H (2018) Sensitivity of European wheat to extreme weather. Field Crops Res 222:209-217. https://doi.org/ 10.1016/j.fcr.2017.11.008

Manners R, Varela-Ortega C, van Etten J (2020) Protein-rich legume and pseudo-cereal crop suitability under present and future European climates. Eur J Agron 113:125974. https://doi.org/10.1016/j.eja. 2019.125974

Mukula J, Rantanen O (1987) Climatic risks to the yield and quality of field crops in Finland. 1. Basic facts about Finnish field crops production. Ann Agric Fenn 26:1-18

Niero M, Ingvordsen $\mathrm{CH}$, Peltonen-Sainio P, Jalli M, Lyngkjær MF, Hauschild MZ, Jørgensen RB (2015) Eco-efficient production of spring barley in a changed climate: a life cycle assessment including primary data from future climate scenarios. Agric Syst 136:46-60. https://doi.org/10.1016/j.agsy.2015.02.007

Olesen JE, Børgesen CD, Elsgaard L, Palosuo T, Rötter RP, Skjelvåg AO, Peltonen-Sainio P, Börjesson T, Trnka M, Ewert F, Siebert S, Brisson N, Eitzinger J, van Asselt ED, Oberforster M, van der FelsKlerx HJ (2012) Changes in time of sowing, flowering and maturity of cereals in Europe under climate change. Eur J Agron 29:15271542. https://doi.org/10.1080/19440049.2012.712060

Peltonen-Sainio P, Jauhiainen L (2019) Unexploited potential to diversify monotonous crop sequencing at high latitudes. Agric Syst 174:7382. https://doi.org/10.1016/j.agsy.2019.04.011

Peltonen-Sainio P, Jauhiainen L, Hannukkala A (2007) Declining rapeseed yields in Finland: how, why and what next. J Agric Sci 145: 587-598. https://doi.org/10.1017/S0021859607007381

Peltonen-Sainio P, Jauhiainen L, Hakala K, Ojanen H (2009a) Climate change and prolongation of growing season: changes in regional for field crop production in Finland. Agric Food Sci 18:171-190

Peltonen-Sainio P, Hakala K, Jauhiainen L, Ruosteenoja K (2009b) Comparing regional risks in producing turnip rape and oilseed rape - impacts of climate change and breeding. Acta Agric Scand Sect B Soil Plant Sci 59:129-138. https://doi.org/10.1080/ 09064710802022895

Peltonen-Sainio P, Jauhiainen L, Hakala K (2011) Crop responses to temperature and precipitation according to long-term multi-location 
trials at high-latitude conditions. J Agric Sci 149:49-62. https://doi. org/10.1017/S0021859610000791

Peltonen-Sainio P, Hannukkala A, Huusela-Veistola E, Voutila L, Niemi J, Valaja J, Jauhiainen L, Hakala K (2013) Potential and realities of enhancing rapeseed-and grain legume-based protein production in a northern climate. J Agric Sci 151:303-321. https://doi.org/10.1017/ S002185961200038X

Peltonen-Sainio P, Venäläinen A, Mäkelä HM, Pirinen P, Laapas M, Jauhiainen L, Kaseva J, Ojanen H, Korhonen P, Huusela-Veistola E, Jalli M, Hakala K, Kaukoranta T, Virkajärvi P (2016) Harmfulness of weather events and the adaptive capacity of farmers at high latitudes of Europe. Clim Res 67:221-240. https://doi.org/ $10.3354 / \mathrm{cr} 01378$

Peltonen-Sainio P, Jauhiainen L, Sorvali J (2017) Diversity of highlatitude agricultural landscapes and crop rotations: increased, decreased or back and forth? Agric Syst 154:25-33. https://doi.org/ 10.1016/j.agsy.2017.02.011

Peltonen-Sainio P, Palosuo T, Ruosteenoja K, Jauhiainen L, Ojanen H (2018) Warming autumns at high latitudes of Europe: an opportunity to lose or gain in cereal production? Reg Environ Chang 18: 1453-1465. https://doi.org/10.1007/s10113-017-1275-5

Peltonen-Sainio P, Sorvali J, Kaseva J (2020) Winds of change for farmers: matches and mismatches between experiences, views and the intention to act. Clim Risk Manag 27:100205. https://doi.org/10. 1016/j.crm.2019.100205

Pullens JWM, Sharif B, Trnka M, Balek J, Semenov MA, Olesen J (2019) Risk factors for European winter oilseed rape production under climate change. Agric Forest Meteor 272:30-39. https://doi.org/10. 1016/j.agrformet.2019.03.023

Qian B, Jing Q, Bélanger G, Shang J, Huffman T, Liu J, Hoogenboom G (2018) Simulated canola yield responses to climate change and adaptation in Canada. Agron J 110:133-146. https://doi.org/10.2134/ agronj2017.02.0076

Ray DK, West PC, Clark M, Gerber JS, Prishchepov AV, Chatterjee S (2019) Climate change has likely already affected global food production. PLoS One 14:e0217148. https://doi.org/10.1371/journal. pone. 0217148

Raymundo R, Asseng S, Robertson R, Petsakos A, Hoogenboom G, Quiroz R, Hareau G, Wolf J (2018) Climate change impact on global potato production. Eur J Agron 100:87-98. https://doi.org/10. 1016/j.eja.2017.11.008

Rötter RP, Palosuo T, Pirttioja NK, Dubrovsky M, Salo T, Fronzek S, Aikasalo R, Trnka M, Ristolainen A, Carter TR (2011) What would happen to barley production in Finland if global warming exceeded $4^{\circ} \mathrm{C}$ ? A model-based assessment. Eur J Agron 35:205-214. https:// doi.org/10.1016/j.eja.2011.06.003
Ruosteenoja K, Räisänen J, Venäläinen A, Kämäräinen M (2016) Projections for the duration and degree days of the thermal growing season in Europe derived from CMIP5 model output. Int J Climatol 36:3039-3055. https://doi.org/10.1002/joc.4535

Ruosteenoja K, Markkanen T, Räisänen J (2019) Thermal seasons in northern Europe in projected future climate. Int J Climatol 33: 1673-1686. https://doi.org/10.1002/joc.6466

Sandström V, Lehikoinen E, Peltonen-Sainio P (2018) Replacing imports of crop based commodities by domestic production in Finland: potential to reduce virtual water imports. Front Sust Food Syst 2:67. https://doi.org/10.3389/fsufs.2018.00067

Scherer LA, Verburg PH, Schulp CJE (2018) Opportunities for sustainable intensification in European agriculture. Glob Environ Chang 48:43-55. https://doi.org/10.1016/j.gloenvcha.2017.11.009

Scoccimarro E, Villarini G, Vichi M, Zampieri M, Fogli PG, Bellucci A, Gualdi S (2015) Projected changes in intense precipitation over Europe at the daily and sub-daily time scales. J Clim 28:61936203. https://doi.org/10.1175/JCLI-D-14-00779.1

Solberg SO, Breian L (2015) Commercial cultivars and farmers' access to crop diversity: a case study from the Nordic region. Agric Food Sci 24:150-163. https://doi.org/10.23986/afsci.48629

Wiréhn L, Käyhkö J, Neset T, Juhola S (2020) Analysing trade-offs in adaptation decision-making - agricultural management under climate change in Finland and Sweden. Reg Environ Chang 20:18. https://doi.org/10.1007/s10113-020-01585-x

Zampieri A, Grizzetti B, Meroni M, Scoccimarro E, Vrieling A, Naumann G, Toreti A (2019) Annual green water resources and vegetation resilience indicators: definitions, mutual relationships, and future climate projections. Remote Sens 11:2708. https://doi. org $/ 10.3390 /$ rs 11222708

Zander P, Amjath-Babu T, Preissel S, Reckling M, Bues A, Schläfke N, Kuhlman T, Bachinger J, Uthes S, Stoddard F, Murphy-Bokern D, Watson C (2016) Grain legume decline and potential recovery in European agriculture: a review. Agr Sust Dev 36:26. https://doi.org/ 10.1007/s13593-016-0365-y

Zhao J, Trnka M, Eitzinger J, Gobin A, Loit E, Peltonen-Sainio P, Palosuo T, Kersebaum C, Ramos MR, Reidsma P, Niinemets U, Holzkämper A, Nendel C, Bindi M, Kozyra J, Nejedlik P, Potopova V, Gaile Z, van Ittersum M, Ferrise R, Olesen JE (2020) Priority of adaptations to climate change in European crop production systems. Manuscript submitted

Publisher's note Springer Nature remains neutral with regard to jurisdictional claims in published maps and institutional affiliations. 